ISSN 1392-3196 / e-ISSN 2335-8947

Zemdirbyste-Agriculture, vol. 102, No. 1 (2015), p. 15-22

DOI 10.13080/z-a.2015.102.002

\title{
Nitrogen cycle bacteria in soils of organically and conventionally managed crop rotations
}

\author{
Malle JÄRVAN, Liina EDESI \\ Estonian Crop Research Institute \\ Teaduse 4/6, 75501 Saku, Estonia \\ E-mail: malle.jarvan@etki.ee
}

\begin{abstract}
The aim of the current research was to investigate the influence of organic and conventional farming on certain bacteria (nitrifiers, denitrifiers and azotobacteria) involved in the soil nitrogen cycle. During 2007-2013, field experiments were performed in Central-Estonia $\left(58^{\circ} 33^{\prime} \mathrm{N}, 25^{\circ} 34^{\prime} \mathrm{E}\right)$ on a sandy loam Albeluvisol $(A B)$ in a five-field crop rotation (winter rye $\rightarrow$ potato $\rightarrow$ oats $\rightarrow$ barley with undersowing $\rightarrow$ red clover). The following treatments were carried out: organic without manure, organic with cattle manure, and conventional where manure, mineral fertilizers and pesticides were used. In the treatments, solid cattle manure $\left(60 \mathrm{t} \mathrm{ha}^{-1}\right)$ was applied for potato. In 2007-2013, soil samples for microbiological tests were taken from the two fields of the crop rotation from 0-20 cm layer. All soil samples were examined for the total number of bacteria, azotobacteria, denitrifying and nitrifying bacteria using the plate-count method.

In the organic farming, the application of cattle manure significantly $(P<0.05)$ increased the total bacteria communities. Also the nitrifying bacteria responded greatly to the soil nutritional status. Their abundance in the organic without manure treatment was significantly $(P<0.05)$ lower than that in the other treatments. There were no significant $(P<0.05)$ differences in the counts of denitrifying bacteria between the treatments. The repeated application of fungicides and insecticides for potato protection decreased the number of azotobacteria as direct effect by 2.7 times and had a harmful aftereffect on these sensitive bacteria also in succeeding years.
\end{abstract}

Key words: azotobacteria, denitrifying and nitrifying bacteria, pesticides, plate-count method, total bacteria, solid cattle manure.

\section{Introduction}

Microorganisms play important roles in the nitrogen cycles of various ecosystems. Research has revealed a great diversity of microorganisms involved in the nitrogen cycle (Hayatsu et al., 2008). The major part of soil nitrogen occurs in organic form and must be mineralized to inorganic nitrogen before it can be taken up by plants.

Nitrogen cycling in agricultural production relies on biological nitrogen fixation primarily by diazotrophic bacteria. Most of biological nitrogen fixation is carried out by diazotrophs in symbiosis with legumes. However, under specific conditions bacteria which are free-living in soil (e.g., Azotobacter and other) may fix significant amounts of nitrogen (Orr et al., 2011). This may be particularly important in organically managed soils, which typically have a lower proportion of nitrogen in available forms.

Bacterial communities are key drivers of soil fertility and agriculture productivity (Tan et al., 2012). The determination of biomass of bacteria and fungi in different soil layers provides information on the soil fertility and soil health (Chhotaray, Achakzai, 2012). It is stated that usually more than $10^{9}$ microorganisms are present per gram of soil and that the biomass of bacteria and fungi can reach up to $3000 \mathrm{~kg}$ per hectare (Haleem et al., 2013). Bacteria make up the major part of the soil microbial community and play significant ecological roles in all soil processes including nutrient cycling (Nannipieri et al., 2003). Soil microflora influences the availability of nutrients for crop production via a range of activities such as the decomposition of crop residues, immobilization of nutrients and mineralization (Bünemann et al., 2006). Enzymes produced by soil microorganisms catalyze biochemical processes involved in nutrient cycling in soil (Scherer et al., 2011; Janušauskaitè et al., 2013).

Complete cycling of mineral nitrogen $(\mathrm{N})$ in soil requires the interplay of microorganisms performing nitrification and denitrification, whose activity is increasingly affected by sufficient moisture and increasing temperature in soil. Nitrification and denitrification represent key processes determining the availability and form of nitrogen in soils and are held responsible for gaseous nitrogen losses as $\mathrm{NO}$ or $\mathrm{N}_{2} \mathrm{O}$, both of which act as potent greenhouse gases (Szukics et al., 2010).

In recent years, multiple studies comparing conventional and organic agriculture have reported differences in soil chemical properties, higher microbial activity and diversity in organically managed soils (Shannon et al., 2002; Monokrousos et al., 2006; Fliessbach et al., 2007). In organic systems, plant production depends primarily on nutrient cycling in soils that are controlled by microbes and their activities 
(Monokrousos et al., 2006). Several investigations on the basis of long term experiments show positive influence of organic farming on soil quality and microbial activity in comparison with conventional farming, due to regular crop rotation, and absence of synthetic nutrients and pesticides (Shannon et al., 2002; Fliessbach et al., 2007; Grantina et al., 2011). As reported by several researchers (Parham et al., 2002; Scherer et al., 2011), the higher diversity of microbial communities and their activities were observed in soils treated with organic amendments, especially with farmyard manure, compared to soils treated with mineral fertilizers. Soil organic matter is the main factor governing levels of microbial biomass in soil, followed by soil $\mathrm{pH}$ (Martyniuk, Martyniuk, 2003; Bünemann et al., 2006). Graham and Haynes (2005) revealed the interaction of soil acidification with negative effects and organic matter accumulation with positive effects on soil organisms and enzyme activities. Microbial populations and their activities are strongly influenced by soil moisture and temperature conditions (Pettersson, Bååth, 2003; Chhotaray, Achakzai, 2012). In conventional farming systems, synthetic pesticides can have a marked effect on the soil microbial community. Among the pesticides, herbicides appeared to have the least significant effects on soil organisms, whereas some insecticides and especially some fungicides proved to be quite toxic (Bünemann et al., 2006). Usually the adverse effects of pesticides are manifested only at concentrations exceeding recommended rates. However, the reaction of Azotobacter, an asymbiotic nitrogen fixer, towards the applied herbicides was highly variable (Lone et al., 2014). Likewise, Miloševic and Govedarica (2002) have shown that Azotobacter is most sensitive to pesticide application; it is, therefore, a reliable indicator of the biological value of soil.

The aim of the current work was to investigate the numbers of total bacteria, nitrifying and denitrifying bacteria and azotobacteria in the soil of a five-field crop rotation in the conditions of different organic farming systems, and to compare these data with numbers of above-mentioned bacteria in the soil of conventionally managed crop rotation. Two hypotheses were tested: 1) the application of solid cattle manure increases the numbers of bacterial groups belonging to the soil nitrogen cycle, and 2) the application of pesticides may significantly decrease the abundance of some bacterial communities.

\section{Materials and methods}

Site and soil description. The experiments were performed in Central-Estonia at Olustvere $\left(58^{\circ} 33^{\prime} \mathrm{N}\right.$, $25^{\circ} 34^{\prime} \mathrm{E}$ ) during 2007-2013. The soil type was sandy loam Albeluvisol $(A B)$ according to the IUSS Working Group WRB (2007) classification. The main soil agrochemical parameters, which are of prime importance for the bacteria living in the soil, are presented in Table 1. The content of available phosphorus in the soil of experimental area at the beginning of research was high (187-210 $\mathrm{mg} \mathrm{kg}^{-1}$, Mehlich-3 method). The content of available potassium varied from moderate to high levels (144-180 mg kg-1, Mehlich-3 method). In the trial area, the field crops have been cultivated according to the principles of organic farming since 2002 .
Table 1. Agrochemical parameters of soils at the beginning (2007) and end (2013) of research

\begin{tabular}{ccccccc}
\hline \multirow{2}{*}{$\begin{array}{c}\text { Location, } \\
\text { soil parameter }\end{array}$} & \multicolumn{8}{c}{ ORG } & \multicolumn{2}{c}{ ORGFYM } & \multicolumn{2}{c}{ CONFYM } \\
& 2007 & 2013 & 2007 & 20013 & 2007 & 20013 \\
\hline \multicolumn{7}{c}{ Field No. 2 } \\
\hline $\mathrm{C}_{\text {org }} \%$ & 1.5 & 1.4 & 1.6 & 1.7 & 1.6 & 1.6 \\
$\mathrm{pH}_{\mathrm{KCl}}$ & 6.0 & 5.8 & 6.3 & 6.1 & 6.1 & 5.7 \\
\hline \multicolumn{7}{c}{ Field No. 4 } \\
\hline $\mathrm{C}_{\text {org }} \%$ & 1.5 & 1.4 & 1.6 & 1.6 & 1.7 & 1.5 \\
$\mathrm{pH}_{\mathrm{KCl}}$ & 5.8 & 5.7 & 5.9 & 5.8 & 6.1 & 5.9 \\
\hline
\end{tabular}

ORG - organic without manure, ORGFYM - organic with manure, CONFYM - conventional where manure, mineral fertilizers and pesticides were used

Experimental set-up. In 2007, the five-field crop rotation was established as follows: winter rye (Secale cereale L.), potato (Solanum tuberosum L.), oats (Avena sativa L.), barley (Hordeum vulgare L.) with undersown red clover (Trifolium pratense L.) and red clover. The size of each field was 1.2 ha, which was divided into three equal parts $(0.4 \mathrm{ha})$ between the cultivation methods. Since 2007, the following treatments were carried out: organic without manure (ORG), organic with solid cattle manure (ORGFYM) and conventional - cattle manure, mineral fertilizers and pesticides were used (CONFYM). The tillage method in all three treatments was the mouldboard ploughing to a depth of $20 \mathrm{~cm}$ in autumn. In all treatments clover was cut and ploughed into the soil in the beginning of July. Straw and crop residues were not removed from the field. Weeds were controlled in the oats and barley fields after sowing and in the rye field at the end of April by spring-tine harrowing. In the potato field the inter-rows were harrowed and cultivated two and three times, respectively. In the ORGFYM and CONFYM treatments, in the rye field after the rye harvesting and prior to the autumn ploughing solid cattle manure at a rate of $60 \mathrm{t} \mathrm{ha}^{-1}$ was applied for potato grown in the next year. Manure contained N 4.7, $\mathrm{P} 1.1$ and $\mathrm{K} 2.7 \mathrm{~kg} \mathrm{t}^{-1}$, as the average of research period. In the CONFYM treatment, mineral fertilizers were applied at the following rates: for potato $-\mathrm{N} 60, \mathrm{P} 60, \mathrm{~K} 120 \mathrm{~kg} \mathrm{ha}^{-1}$, oats - N 72, P 18, K $36 \mathrm{~kg} \mathrm{ha}^{-1}$, barley with undersown clover $-\mathrm{N} 48, \mathrm{P} 12, \mathrm{~K} 24 \mathrm{~kg} \mathrm{ha}^{-1}$, winter rye $-\mathrm{N} \mathrm{15,} \mathrm{P} 30$, $\mathrm{K} 75 \mathrm{~kg} \mathrm{ha}^{-1}$ in autumn and N $34 \mathrm{~kg} \mathrm{ha}^{-1}$ twice in spring. In the CONFYM treatment, pesticides were applied at the dates and doses given in Table 2.

Weather conditions. The weather conditions during research period are shown in Table 3. During this seven-year period, the weather conditions in the vegetation period were quite different. The growing seasons 2008 and 2012 were very rainy but 2011 and 2013 were extremely dry and warm. In 2008 and 2010, the end of summer was characterized by very great amounts of precipitation (total in August and September 243 and $220 \mathrm{~mm}$ ) which temporarily caused short-term flooding of soil. The spring of 2009 differed among other springs with less precipitation because it rained only 14 $\mathrm{mm}$ in total in April and May. The vegetation periods of 2008 and 2012 were the coldest with $12.5^{\circ} \mathrm{C}$ and $12.4^{\circ} \mathrm{C}$ as an average for six months' period. In July 2010 and 2011, extraordinarily hot air temperatures prevailed, up to $22.4^{\circ} \mathrm{C}$ as a monthly average. Unexpectedly warm were May and June of 2013 , up to $3-4^{\circ} \mathrm{C}$ higher than the multi-annual average. 
Table 2. The use of pesticides in the CONFYM treatment on the crop rotation fields No. 2 and No. 4 during the research period (2007-2013)

\begin{tabular}{|c|c|c|c|c|c|c|}
\hline Year & Date & Crop & Category & $\begin{array}{c}\text { Commercial } \\
\text { name }\end{array}$ & Active ingredients & $\begin{array}{c}\text { Dose per } \\
\text { hectare }\end{array}$ \\
\hline \multicolumn{7}{|c|}{ Field No. 2} \\
\hline 2007 & May 10 & winter rye & herbicide & Sekator OD & $\begin{array}{l}\text { amidosulfuron }\left(100 \mathrm{~g} \mathrm{l}^{-1}\right), \\
\text { methyl-iodosulfuron-sodium }\left(25 \mathrm{~g} \mathrm{l}^{-1}\right) \\
\text { mefenpyr-diethyl }\left(250 \mathrm{~g} \mathrm{l}^{-1}\right)\end{array}$ & 0.151 \\
\hline \multirow[t]{6}{*}{2008} & June 19 & potato & herbicide & Titus $25 \mathrm{DF}$ & rimsulfuron $\left(250 \mathrm{~g} \mathrm{~kg}^{-1}\right)$ & $50 \mathrm{~g}$ \\
\hline & & & fungicide & Ridomil Gold & metalaxyl $\left(40 \mathrm{~g} \mathrm{~kg}^{-1}\right)$, mancoceb $\left(640 \mathrm{~g} \mathrm{~kg}^{-1}\right)$ & $2.5 \mathrm{~kg}$ \\
\hline & July 4 & & fungicide & Shirlan $500 \mathrm{SC}$ & fluazinam $\left(500 \mathrm{~g} \mathrm{l}^{-1}\right)$ & 0.71 \\
\hline & July 11 & & fungicide & Shirlan $500 \mathrm{SC}$ & fluazinam $\left(500 \mathrm{~g} \mathrm{l}^{-1}\right)$ & 0.31 \\
\hline & July 24 & & fungicide & Ranman & cyazofamid $\left(400 \mathrm{~g} \mathrm{l}^{-1}\right)$ & 0.21 \\
\hline & & & insecticide & Danadim $40 \mathrm{EC}$ & dimethoate $\left(400 \mathrm{~g} \mathrm{l}^{-1}\right)$ & 0.51 \\
\hline 2009 & May 30 & oats & herbicide & Sekator OD & $\begin{array}{l}\text { amidosulfuron }\left(100 \mathrm{~g} \mathrm{l}^{-1}\right), \\
\text { methyl-iodosulfuron-sodium }\left(25 \mathrm{~g} \mathrm{l}^{-1}\right) \\
\text { mefenpyr-diethyl }\left(250 \mathrm{~g} \mathrm{l}^{-1}\right)\end{array}$ & 0.151 \\
\hline 2010 & May 31 & barley & herbicide & MCPA & $\operatorname{MCPA}\left(750 \mathrm{~g} \mathrm{l}^{-1}\right)$ & $0.9 \mathrm{~kg}$ \\
\hline 2012 & May 9 & winter rye & herbicide & Mustang Forte & $\begin{array}{c}\text { florasulam }\left(5 \mathrm{~g} \mathrm{l}^{-1}\right), 2.4-\mathrm{D}\left(180 \mathrm{~g} \mathrm{l}^{-1}\right) \\
\text { aminopyralid }\left(10 \mathrm{~g} \mathrm{l}^{-1}\right),\end{array}$ & 0.71 \\
\hline \multirow[t]{5}{*}{2013} & May 31 & potato & herbicide & Mistral $700 \mathrm{WG}$ & metribuzin $\left(700 \mathrm{~g} \mathrm{~kg}^{-1}\right)$ & $0.5 \mathrm{~kg}$ \\
\hline & June 20 & & fungicide & Ridomil Gold & metalaxyl $\left(40 \mathrm{~g} \mathrm{~kg}^{-1}\right)$, mancoceb $\left(640 \mathrm{~g} \mathrm{~kg}^{-1}\right)$ & $2.5 \mathrm{~kg}$ \\
\hline & July 4 & & fungicide & Shirlan $500 \mathrm{SC}$ & fluazinam $\left(500 \mathrm{~g} \mathrm{l}^{-1}\right)$ & 0.31 \\
\hline & & & insecticide & Fastac 50 & alpha-cypermetrin $\left(50 \mathrm{~g} \mathrm{l}^{-1}\right)$ & 0.31 \\
\hline & July 26 & & fungicide & Shirlan $500 \mathrm{SC}$ & fluazinam $\left(500 \mathrm{~g} \mathrm{l}^{-1}\right)$ & 0.31 \\
\hline \multicolumn{7}{|c|}{ Field No. 4} \\
\hline \multirow[t]{8}{*}{2007} & June 13 & potato & herbicide & Titus $25 \mathrm{DF}$ & rimsulfuron $\left(250 \mathrm{~g} \mathrm{~kg}^{-1}\right)$ & $50 \mathrm{~g}$ \\
\hline & June 21 & & fungicide & Ridomil Gold & metalaxyl $\left(40 \mathrm{~g} \mathrm{~kg}^{-1}\right)$, mancoceb $\left(640 \mathrm{~g} \mathrm{~kg}^{-1}\right)$ & $2.5 \mathrm{~kg}$ \\
\hline & July 11 & & fungicide & Shirlan $500 \mathrm{SC}$ & fluazinam $\left(500 \mathrm{~g} \mathrm{l}^{-1}\right)$ & 0.41 \\
\hline & & & insecticide & Fastac 50 & alpha-cypermetrin $\left(50 \mathrm{~g} \mathrm{l}^{-1}\right)$ & 0.31 \\
\hline & July 17 & & fungicide & Shirlan $500 \mathrm{SC}$ & fluazinam $\left(500 \mathrm{~g} \mathrm{l}^{-1}\right)$ & 0.31 \\
\hline & & & insecticide & Decis & deltametrin $\left(50 \mathrm{~g} \mathrm{l}^{-1}\right)$ & 0.151 \\
\hline & July 30 & & fungicide & Ranman & cyazofamid $\left(400 \mathrm{~g} \mathrm{l}^{-1}\right)$ & 0.21 \\
\hline & & & insecticide & Fastac 50 & alpha-cypermetrin $\left(50 \mathrm{~g} \mathrm{l}^{-1}\right)$ & 0.31 \\
\hline 2008 & May 16 & oats & herbicide & Sekator OD & $\begin{array}{l}\text { amidosulfuron }\left(100 \mathrm{~g} \mathrm{l}^{-1}\right), \\
\text { methyl-iodosulfuron-sodium }\left(25 \mathrm{~g} \mathrm{l}^{-1}\right) \\
\text { mefenpyr-diethyl }\left(250 \mathrm{~g} \mathrm{l}^{-1}\right)\end{array}$ & 0.151 \\
\hline 2009 & May 30 & barley & herbicide & MCPA & $\operatorname{MCPA}\left(750 \mathrm{~g} \mathrm{l}^{-1}\right)$ & $0.9 \mathrm{~kg}$ \\
\hline 2011 & May 5 & $\begin{array}{l}\text { winter } \\
\text { rye }\end{array}$ & herbicide & Sekator OD & $\begin{array}{l}\text { amidosulfuron }\left(100 \mathrm{~g} \mathrm{l}^{-1}\right), \\
\text { methyl-iodosulfuron-sodium }\left(25 \mathrm{~g} \mathrm{l}^{-1}\right) \\
\text { mefenpyr-diethyl }\left(250 \mathrm{~g} \mathrm{l}^{-1}\right)\end{array}$ & 0.151 \\
\hline \multirow[t]{8}{*}{2012} & June 12 & potato & herbicide & Sencor & metribuzin $\left(700 \mathrm{~g} \mathrm{~kg}^{-1}\right)$ & $0.5 \mathrm{~kg}$ \\
\hline & June 21 & & fungicide & Ridomil Gold & metalaxyl $\left(40 \mathrm{~g} \mathrm{~kg}^{-1}\right)$, mancoceb $\left(640 \mathrm{~g} \mathrm{~kg}^{-1}\right)$ & $2.5 \mathrm{~kg}$ \\
\hline & July 4 & & fungicide & Shirlan $500 \mathrm{SC}$ & fluazinam $\left(500 \mathrm{~g} \mathrm{l}^{-1}\right)$ & 0.31 \\
\hline & & & insecticide & Fastac 50 & alpha-cypermetrin $\left(50 \mathrm{~g} \mathrm{l}^{-1}\right)$ & 0.31 \\
\hline & July 13 & & fungicide & Shirlan $500 \mathrm{SC}$ & fluazinam $\left(500 \mathrm{~g} \mathrm{l}^{-1}\right)$ & 0.31 \\
\hline & July 20 & & fungicide & Shirlan $500 \mathrm{SC}$ & fluazinam $\left(500 \mathrm{~g} \mathrm{l}^{-1}\right)$ & 0.31 \\
\hline & & & insecticide & Fastac 50 & alpha-cypermetrin $\left(50 \mathrm{~g} \mathrm{l}^{-1}\right)$ & 0.31 \\
\hline & August 2 & & fungicide & Ridomil Gold & metalaxyl $\left(40 \mathrm{~g} \mathrm{~kg}^{-1}\right)$, mancoceb $\left(640 \mathrm{~g} \mathrm{~kg}^{-1}\right)$ & $2.5 \mathrm{~kg}$ \\
\hline 2013 & May 30 & oats & herbicide & $\begin{array}{l}\text { Tomigan } 180 \mathrm{EC} \\
+ \text { Trimmer } 50 \mathrm{SG}\end{array}$ & $\begin{array}{c}\text { fluroxypyr }\left(180 \mathrm{~g} \mathrm{l}^{-1}\right) \\
\text { methyltribenuron }\left(500 \mathrm{~g} \mathrm{~kg}^{-1}\right)\end{array}$ & $\begin{array}{l}0.51 \\
18 \mathrm{~g}\end{array}$ \\
\hline
\end{tabular}

Soil sampling. The soil samples for microorganism determination were taken from the fields No. 2 and No. 4 because one of the crucial problems of our project was to compare the effects of the organic management with and without farmyard manure. On these crop rotation fields cattle manure was applied in the first years (2007 and 2008) of the research period. Soils were sampled in 2007-2010 and 2013 in September, and in 2009-2011 in May. In 2012 and in September 2011, the microbiological tests were not carried out. The soil samples from each treatment were taken according to the guide of Agricultural Research Centre located in Saku, Estonia. The soil samples were taken from 45 randomly selected points of each treatment from the $0-20 \mathrm{~cm}$ soil layer using an auger with a $1 \mathrm{~cm}$ diameter. The composite sample was carefully mixed and divided into three replicates. To avoid contamination of soil samples, the preventive measures accordingly to the guide were taken. Soil samples had been kept at $4^{\circ} \mathrm{C}$ until they were analyzed in the laboratory. 
Table 3. Monthly total precipitation and average air temperatures during 2007-2013

\begin{tabular}{|c|c|c|c|c|c|c|c|}
\hline \multirow{2}{*}{ Month } & \multicolumn{7}{|c|}{ Year } \\
\hline & 2007 & 2008 & 2009 & 2010 & 2011 & 2012 & 2013 \\
\hline \multicolumn{8}{|c|}{ Precipitation $\mathrm{mm}$} \\
\hline April & 24 & 47 & 2 & 12 & 11 & 51 & 40 \\
\hline May & 54 & 23 & 12 & 53 & 58 & 68 & 75 \\
\hline June & 62 & 120 & 85 & 48 & 20 & 96 & 20 \\
\hline July & 98 & 47 & 125 & 43 & 64 & 119 & 51 \\
\hline August & 63 & 176 & 95 & 138 & 82 & 75 & 82 \\
\hline September & 67 & 67 & 71 & 82 & 65 & 60 & 14 \\
\hline Total & 368 & 480 & 390 & 376 & 300 & 469 & 282 \\
\hline \multicolumn{8}{|c|}{ Temperature ${ }^{\circ} \mathrm{C}$} \\
\hline April & 5.4 & 7.4 & 6.4 & 6.0 & 6.8 & 4.7 & 3.7 \\
\hline May & 12.0 & 10.9 & 11.5 & 12.1 & 11.2 & 10.9 & 14.5 \\
\hline June & 16.6 & 14.5 & 14.1 & 14.8 & 17.9 & 13.0 & 18.3 \\
\hline July & 16.8 & 16.5 & 17.2 & 22.4 & 20.3 & 17.6 & 17.9 \\
\hline August & 18.0 & 15.8 & 15.8 & 18.5 & 16.6 & 15.9 & 17.3 \\
\hline September & 11.2 & 10.0 & 12.8 & 11.2 & 12.7 & 12.0 & 11.5 \\
\hline Average & 13.3 & 12.5 & 13.0 & 14.2 & 14.3 & 12.4 & 13.9 \\
\hline
\end{tabular}

Microbiological analyses. All soil samples were examined in the Microbiological Laboratory of Agricultural Research Centre for the total number of bacteria, moulds, yeasts, mesophilic spore-forming bacteria, Fusarium spp., actinomycetes, cellulose decomposing bacteria, azotobacteria, denitrifying and nitrifying bacteria using the plate-count method. The current paper discusses only the results of total bacteria, denitrifying and nitrifying bacteria and azotobacteria. Decimal dilution series were prepared in accordance with EVS-EN ISO 6887-1:2001. Microbiological counts were expressed as a number of colony forming units (CFU) $\mathrm{g}^{-1}$ of dry soil. Plate count agar was used for isolation of total number of bacteria at $30^{\circ} \mathrm{C}$ for $72 \mathrm{~h}$ (NMKL No. 86, 2006, ICC No. 125, 1978 and EVS-EN ISO 4833$1: 2013)$. To identify the azotobacteria the Ashby culture media was used. The nitrifying bacteria were defined on water agar. For denitrifying bacteria the Hiltay culture media was used.

Data analyses. All results were based on three or two (plate count microorganisms) soil replicates. The data were analyzed by ANOVA. The Tukey-Kramer honestly significant difference (HSD) test was used, using the software JMP 5.0.1.2 (2002; SAS Institute, Cary, USA).

\section{Results and discussion}

Total bacteria. Bacterial communities are the prevalent groups among the microorganisms living in soil. In our seven-year experiments, the highest number of total bacteria was revealed in September 2010 in the both organic treatments (ORG and ORGFYM) when it reached $12.43 \times 10^{6} \mathrm{CFU} \mathrm{g}^{-1}$ dry soil (Table 4). In that case red clover undersown in barley produced an opulent vegetation mass in September. The abundant herbage mass and the vigorous root system of clover likely favoured the reproduction of bacterial communities. Likewise, other researchers have reported a good impact of red clover on soil microorganisms. By Chhotaray and Achakzai (2012), soil microbial biomass levels were generally higher in treatments with red clover and the number of microbes increased significantly $(P<0.01)$ from May to the second sampling date in September. Also Miller et al. (2012) indicated that the cropping of red clover caused increased abundance in the soil total bacteria. On

Table 4. The influence of farming methods on soil microbial communities in the experimental field No. 2

\begin{tabular}{|c|c|c|c|c|c|c|c|c|c|}
\hline \multirow{3}{*}{$\begin{array}{c}\text { Microorganisms } \\
\text { CFU g-1 } \\
\text { dry soil }\end{array}$} & \multirow{3}{*}{ Treatment } & \multicolumn{8}{|c|}{ Year, crop and month of microbe determination } \\
\hline & & \multirow{2}{*}{$\begin{array}{c}\begin{array}{c}2008 \\
\text { potato }\end{array} \\
\text { September }\end{array}$} & \multicolumn{2}{|c|}{$\begin{array}{c}2009 \\
\text { oats }\end{array}$} & \multicolumn{2}{|c|}{$\begin{array}{l}\text { 2010, barley with } \\
\text { undersown clover }\end{array}$} & \multirow{2}{*}{\begin{tabular}{|c|}
$\begin{array}{c}2011 \\
\text { clover }\end{array}$ \\
April
\end{tabular}} & \multirow{2}{*}{$\begin{array}{c}\begin{array}{c}2013 \\
\text { potato }\end{array} \\
\text { September }\end{array}$} & \multirow[t]{2}{*}{ Average } \\
\hline & & & May & September & May & September & & & \\
\hline \multirow{3}{*}{$\begin{array}{l}\text { Total bacteria } \\
\quad \times 10^{6}\end{array}$} & ORG & $8.53 \mathrm{~b}$ & $5.00 \mathrm{~b}$ & $6.07 \mathrm{~b}$ & $4.21 \mathrm{~b}$ & $11.91 \mathrm{a}$ & $3.64 \mathrm{a}$ & $7.07 \mathrm{~b}$ & $6.63 \mathrm{~b}$ \\
\hline & ORGFYM & $10.80 \mathrm{a}$ & $7.27 \mathrm{a}$ & $7.93 \mathrm{a}$ & $7.07 \mathrm{a}$ & $12.43 \mathrm{a}$ & $2.51 \mathrm{a}$ & $8.95 \mathrm{ab}$ & $8.14 \mathrm{a}$ \\
\hline & CONFYM & $8.55 \mathrm{~b}$ & $5.60 \mathrm{~b}$ & $7.73 \mathrm{a}$ & $6.29 \mathrm{a}$ & $9.85 \mathrm{a}$ & $3.04 \mathrm{a}$ & $10.60 \mathrm{a}$ & $7.38 \mathrm{ab}$ \\
\hline \multirow{3}{*}{$\begin{array}{l}\text { Denitrifying bacteria } \\
\quad \times 10^{5}\end{array}$} & ORG & $6.30 \mathrm{a}$ & $2.12 \mathrm{~b}$ & $5.21 \mathrm{a}$ & $7.22 \mathrm{a}$ & $1.84 \mathrm{a}$ & - & $1.07 \mathrm{a}$ & $3.96 \mathrm{a}$ \\
\hline & ORGFYM & $2.35 \mathrm{~b}$ & $2.14 \mathrm{~b}$ & $5.42 \mathrm{a}$ & $5.74 \mathrm{a}$ & $0.60 \mathrm{a}$ & - & $0.32 \mathrm{a}$ & $2.76 \mathrm{a}$ \\
\hline & CONFYM & $5.27 \mathrm{ab}$ & $8.10 \mathrm{a}$ & $3.08 \mathrm{a}$ & $2.68 \mathrm{~b}$ & $0.44 \mathrm{a}$ & - & $2.09 \mathrm{a}$ & $3.61 \mathrm{a}$ \\
\hline \multirow{3}{*}{$\begin{array}{l}\text { Nitrifying bacteria } \\
\times 10^{4}\end{array}$} & ORG & $1.07 \mathrm{~b}$ & $1.85 \mathrm{~b}$ & $2.58 \mathrm{~b}$ & $1.40 \mathrm{~b}$ & $2.34 \mathrm{~b}$ & $1.12 \mathrm{a}$ & $1.05 \mathrm{~b}$ & $1.63 \mathrm{~b}$ \\
\hline & ORGFYM & $6.70 \mathrm{a}$ & $4.84 \mathrm{a}$ & $3.37 \mathrm{~b}$ & $2.75 \mathrm{ab}$ & $3.50 \mathrm{a}$ & $1.34 \mathrm{a}$ & $2.53 \mathrm{a}$ & $3.58 \mathrm{a}$ \\
\hline & CONFYM & $4.86 \mathrm{ab}$ & $4.87 \mathrm{a}$ & $6.46 \mathrm{a}$ & $3.13 \mathrm{a}$ & $2.86 \mathrm{ab}$ & $1.21 \mathrm{a}$ & $2.92 \mathrm{a}$ & $3.06 \mathrm{a}$ \\
\hline \multirow{3}{*}{$\begin{array}{l}\text { Azotobacteria } \\
\times 10^{1}\end{array}$} & ORG & $12.20 \mathrm{a}$ & $17.59 \mathrm{a}$ & $12.45 \mathrm{a}$ & $4.15 \mathrm{a}$ & $3.71 \mathrm{a}$ & - & $4.04 \mathrm{a}$ & $9.02 \mathrm{a}$ \\
\hline & ORGFYM & $15.90 \mathrm{a}$ & $9.54 \mathrm{a}$ & $18.53 \mathrm{a}$ & $3.78 \mathrm{a}$ & $7.13 \mathrm{a}$ & - & $1.50 \mathrm{~b}$ & $9.40 \mathrm{a}$ \\
\hline & CONFYM & $5.86 \mathrm{~b}$ & $2.90 \mathrm{~b}$ & $5.04 \mathrm{~b}$ & $1.38 \mathrm{~b}$ & $5.55 \mathrm{a}$ & - & $0 \mathrm{~b}$ & $3.46 \mathrm{~b}$ \\
\hline
\end{tabular}

Notes. CFU - colony forming units; ORG - organic without manure, ORGFYM - organic with manure, CONFYM - conventional where manure, mineral fertilizers and pesticides were used. Different letters behind the mean values indicate significant differences $(P<0.05)$ in a category. 
the other hand, it is well known that the abundance and activity of microbial communities is strongly dependent on the soil environmental conditions. As affirmed by several researchers (Pettersson, Bååth, 2003; Lipson, 2007; Lauber et al., 2013), among these the soil moisture and temperature have a cardinal importance. By Pettersson and Bååth (2003), strong seasonal effects and interactions between the sampling date and crop management factors were detected, whereby temperature was one of the most important environmental factors affecting the soil bacterial community. The study of Lipson (2007) who examined the temporal variability in soil microbial communities indicated that the composition of bacterial communities can vary between the seasons. In some cases the changes in these communities can be linked to changes in soil environment conditions. Lauber et al. (2013) have investigated changes in microbial communities of soils collected on a monthly basis from May to November. They indicated that communities in the agricultural soils were most variable over time and the changes were significantly correlated with soil moisture and temperature.

Likewise, the results of our research showed that the number of total bacteria in the soil depended on the weather conditions. As mentioned above, the highest numbers of total bacteria were registered in September 2010 . There was a very rainy and warm period before the soil sampling for microbe determination because the total precipitation in August and September reached $220 \mathrm{~mm}$, and the monthly air temperatures in July and August were considerably higher than in the other years of our research (Table 3). In 2008, there was a very rainy growing period, too. During six months total precipitation of $480 \mathrm{~mm}$ was accumulated but while the weather in 2008 was colder than usual the total bacteria communities in the soils of the fields No. 2 and No. 4 remained on the moderate levels (Table 5). Comparison of the results of the microbiological tests in spring and autumn in the same year revealed that the abundance of total bacteria in spring was in most cases lower than in autumn. This may be explained by lower soil temperatures and sometimes (in 2009) by deficient soil moisture in early spring.

Comparison of the occurrence of the bacterial communities in the conditions of two organic treatments (ORGFYM and ORG) showed that the number of total bacteria in the soil of ORGFYM treatment was significantly $(P<0.05)$ higher than in the soil of ORG

Table 5. The influence of farming methods on soil microbial communities in the experimental field No. 4

\begin{tabular}{|c|c|c|c|c|c|c|c|c|c|c|}
\hline \multirow{3}{*}{$\begin{array}{l}\text { Microorganisms } \\
\text { CFU g-1 } \\
\text { dry soil }\end{array}$} & \multirow{3}{*}{ Treatment } & \multicolumn{9}{|c|}{ Year, crop and month of microbe determination } \\
\hline & & \multirow{2}{*}{\begin{tabular}{|l|}
2007 \\
potato \\
August
\end{tabular}} & \multirow{2}{*}{$\begin{array}{c}\begin{array}{c}2008 \\
\text { oats }\end{array} \\
\text { September }\end{array}$} & \multicolumn{2}{|c|}{$\begin{array}{l}\text { 2009, barley with } \\
\text { undersown clover }\end{array}$} & \multicolumn{2}{|c|}{$\begin{array}{l}2010 \\
\text { clover }\end{array}$} & \multirow{2}{*}{$\begin{array}{c}\begin{array}{c}2011 \\
\text { rye }\end{array} \\
\text { April }\end{array}$} & \multirow{2}{*}{$\begin{array}{c}\begin{array}{c}2013 \\
\text { oats }\end{array} \\
\text { September }\end{array}$} & \multirow[t]{2}{*}{ Average } \\
\hline & & & & May & September & May & September & & & \\
\hline \multirow{3}{*}{$\begin{array}{l}\text { Total bacteria } \\
\quad \times 10^{6}\end{array}$} & & $5.97 \mathrm{~b}$ & $7.96 \mathrm{~b}$ & $2.90 \mathrm{~b}$ & $4.32 \mathrm{a}$ & $5.98 \mathrm{~b}$ & $8.07 \mathrm{a}$ & $2.31 \mathrm{~b}$ & $8.67 \mathrm{a}$ & $7 \mathrm{~b}$ \\
\hline & $\mathrm{RG}$ & $9.24 \mathrm{a}$ & $\mathrm{a}$ & $4.76 \mathrm{a}$ & & $8.74 \mathrm{a}$ & & & & \\
\hline & CONFYM & $5.02 \mathrm{~b}$ & $10.0 \mathrm{a}$ & $5.54 \mathrm{a}$ & & $10.1 \mathrm{a}$ & & $3.8 \mathrm{ab}$ & $5.45 \mathrm{~b}$ & $6.76 \mathrm{ab}$ \\
\hline \multirow{3}{*}{$\begin{array}{l}\text { Denitrifying bacteria } \\
\qquad \times 10^{5}\end{array}$} & ORG & & & & & & & - & $2.77 \mathrm{a}$ & \\
\hline & ORGH & & $5.23 \mathrm{a}$ & & & 3. & & - & $3.03 \mathrm{a}$ & $5 \mathrm{a}$ \\
\hline & CONFYM & $2.82 \mathrm{~b}$ & $5.22 \mathrm{a}$ & $08 \mathrm{a}$ & & $4.22 \mathrm{a}$ & & - & $2.07 \mathrm{a}$ & $3.17 \mathrm{a}$ \\
\hline \multirow{3}{*}{$\begin{array}{l}\text { Nitrifying bacteria } \\
\quad \times 10^{4}\end{array}$} & ORG & $1.66 \mathrm{a}$ & $1.05 \mathrm{~b}$ & $2.5 \mathrm{ab}$ & $2 \mathrm{~b}$ & $1.41 \mathrm{~b}$ & $2.15 \mathrm{~b}$ & $0.95 \mathrm{a}$ & $1.16 \mathrm{~b}$ & $1.62 \mathrm{~b}$ \\
\hline & ORGFYM & $1.91 \mathrm{a}$ & $2.16 \mathrm{a}$ & $1.93 \mathrm{~b}$ & $4.96 \mathrm{a}$ & $2.85 \mathrm{a}$ & $3.52 \mathrm{a}$ & $1.16 \mathrm{a}$ & $2.43 \mathrm{a}$ & $2.62 \mathrm{a}$ \\
\hline & CONFYM & $2.35 \mathrm{a}$ & $2.93 \mathrm{a}$ & $3.39 \mathrm{a}$ & $4.43 \mathrm{a}$ & $2.84 \mathrm{a}$ & $3.68 \mathrm{a}$ & $0.99 \mathrm{a}$ & $2.85 \mathrm{a}$ & $2.93 \mathrm{a}$ \\
\hline \multirow{3}{*}{$\begin{array}{l}\text { Azotobacteria } \\
\quad \times 10^{1}\end{array}$} & ORG & - & $2.31 \mathrm{a}$ & $1.70 \mathrm{a}$ & $2.88 \mathrm{a}$ & $5.35 \mathrm{a}$ & $0.58 \mathrm{a}$ & - & $3.88 \mathrm{a}$ & $2.78 \mathrm{a}$ \\
\hline & ORGFY & - & $2.33 \mathrm{a}$ & $0.76 \mathrm{a}$ & $0.77 \mathrm{a}$ & $0.94 \mathrm{~b}$ & $3.10 \mathrm{a}$ & - & $2.62 \mathrm{a}$ & $1.75 \mathrm{a}$ \\
\hline & CONFYM & - & $2.90 \mathrm{a}$ & $1.52 \mathrm{a}$ & $0.38 \mathrm{a}$ & $1.53 \mathrm{~b}$ & $1.74 \mathrm{a}$ & - & $0.75 \mathrm{a}$ & $1.47 \mathrm{a}$ \\
\hline
\end{tabular}

Notes. CFU - colony forming units; ORG - organic without manure, ORGFYM - organic with manure, CONFYM - conventional where manure, mineral fertilizers and pesticides were used. Different letters behind the mean values indicate significant differences $(P<0.05)$ in a category.

treatment in nine cases out of fifteen (Tables 4-5). In the crop rotation field No. 2, the great aftereffects of manure were observed in May of 2009 and 2010 when the numbers of total bacteria in the soil of the ORGFYM treatment were by $45.4 \%$ and $67.9 \%$ higher than those in the soil of ORG treatment. Approximately the same aftereffect of manure was revealed in the field No. 4 where the levels of total bacteria at the above mentioned sampling dates in the soil of ORGFYM treatment were by $64.1 \%$ and $46.2 \%$ higher than in the soil of ORG treatment. In the organic treatments, the highest direct effect of cattle manure applied for potato was proved in the weather conditions of 2007, while the number of total bacteria in the soil of ORGFYM treatment was $9.24 \times 10^{6} \mathrm{CFU} \mathrm{g}^{-1}$ dry soil, i.e. by $54.8 \%$ higher than in the soil of ORG treatment. In the conditions of 2008 , the application of manure for organic potato increased the community of total bacteria up to $10.80 \times 10^{6} \mathrm{CFU} \mathrm{g}^{-1}$ dry soil, i.e. by $26.6 \%$ more than without manure. According to the experiment planning, cattle manure at the rate $60 \mathrm{t} \mathrm{ha}^{-1}$ was applied once during the five-field crop rotation. But during the experiment period manure for potato was applied in two years (on the field No. 2 - in 2008 and 2013, and on the field No. 4 - in 2007 and 2012). In the conditions of our experiment, the use of manure in organic crop rotation increased the number of total bacteria by $22.8 \%$ to $38.1 \%$, as an average of microbiological tests during experiment period. Our results are in accordance with those of other authors (Parham et al., 2002; Fliessbach et al., 2007; Scherer et al., 2011) who have shown that manure positively affected the abundance and activity of soil microbial communities.

In our experiments during 2007-2013, the influence of ORGFYM and CONFYM treatments on the soil bacterial communities was compared. The results showed that in the numbers of total bacteria between ORGFYM and CONFYM treatments there were no significant $(P<0.05)$ differences, as an average for 2007-2013 (Tables 4-5). However, in four cases in the soil of CONFYM treatment the levels of total bacteria were significantly $(P<0.05)$ lower than in the soil of ORGFYM treatment. In September 2007 on the field 
No. 4 where potato was grown, in the soil of CONFYM treatment the count of total bacteria was only $5.02 \times 10^{6}$ CFU g ${ }^{-1}$ dry soil, i.e. by $45.7 \%$ less than in the ORGFYM treatment. We supposed that the repeated application of pesticides, especially when spraying four times with fungicides for the control of late blight, and when spraying three times with insecticides for the control of aphides and Colorado beetle, affected negatively the soil bacterial communities. In 2008 , when potato was grown in the field No. 2 the number of total bacteria in the soil of CONFYM treatment was by $20.8 \%$ smaller than in the ORGFYM treatment. The reason for that decrease in bacterial communities was also the repeated application of pesticides because during the growing season the potato plants were sprayed four times with fungicides and once with insecticide Danadim for aphides control. The active ingredient of the insecticide Danadim is dimethoate. As reported by Haleem et al. (2013), the insecticide dimethoate significantly $(P<0.05)$ decreased the count of total bacteria by $24-60 \%$, depending on the doses used and sampling periods after insecticide application. The significant decrease in the total bacteria was observed also in the soil of the oats field (May 2009 on the field No. 2 and September 2013 on the field No. 4) while their count in the CONFYM treatment was by $23.0 \%$ and $42.5 \%$ less than that in the ORGFYM treatment. In these cases the aftereffect of an abundant application of pesticides to preceding potato became evident.

Herbicides, in general, slightly affect soil microbial communities (Banks et al., 2014; Lone et al., 2014). However, some herbicides can have a harmful influence on the soil bacteria. For example, Radivojevic et al. (2003) have established a significant $(P<0.05)$ negative effect of metribuzin on soil bacterial and fungal populations. In our experiment, metribuzin as an active ingredient of herbicide Mistral was used for weed control in potato (in 2012 and 2013) and this might increase the negative total effect of pesticides in the soil of CONFYM treatment. All the analysed factors, i.e. treatment, and year had significant impacts on the number of total bacteria (Table 6).

Denitrifying bacteria. Denitrifying bacteria are more numerous than any other functional groups involved in the nitrogen cycle (Clark et al., 2012). Nitrate reduction by denitrification is of great importance because it can lead to considerable nitrogen losses in agriculture and emissions of greenhouse gases (Cheneby et al., 2009). In general, activity of this process increases with soil temperature and moisture and is strongly dependent on soil physiochemical properties especially on soil organic carbon content (Szukics et al., 2010; Clark et al., 2012; Miller et al., 2012). According to the findings of Cheneby et al. (2009), nitrate reduction activity was stimulated by combined organic and mineral fertilization but not by organic fertilization alone. In our experiments, denitrifying bacteria reacted clearly neither to the different weather conditions nor to the farming treatments. As an average of 2007 (or 2008)-2013, there were no significant $(P<0.05)$ differences in the counts of denitrifying bacteria between treatments (Tables 4-5). One reason for that might be the great differences between three replications of samples. However, in some cases the influence of treatments was expressed significantly $(P<0.05)$ but the changes in the numbers of denitrifying bacteria were not in the same direction. For example, in the field No. 2 in May 2009 the count of denitrifiers in
Table 6. The influence of farming methods and year on soil microbial communities

\begin{tabular}{ccccc}
\hline \multirow{2}{*}{ Variables } & $\begin{array}{c}\text { Total number Denitrifying } \\
\text { of bacteria }\end{array}$ & $\begin{array}{c}\text { Nitrifying } \\
\text { bacteria }\end{array}$ & $\begin{array}{c}\text { Azoto- } \\
\text { bacteria }\end{array}$ & bacteria \\
\hline \multicolumn{5}{c}{ Field No. 2} \\
\hline Treatment & 0.049 & n.s. & $<0.001$ & 0.039 \\
Year & 0.001 & n.s. & $<0.001$ & 0.027 \\
\hline \multicolumn{5}{c}{ Field No. 4} \\
\hline Treatment & $<0.001$ & n.s. & 0.035 & n.s. \\
Year & $<0.001$ & n.s. & 0.001 & n.s. \\
\hline \multicolumn{5}{c}{ Average } \\
\hline $\begin{array}{c}\text { Treatment } \\
\text { Year }\end{array}$ & 0.027 & n.s. & $<0.001$ & n.s. \\
Treatment $\times$ & $<0.001$ & n.s. & $<0.001$ & n.s. \\
year & n.s. & n.s. & 0.019 & n.s. \\
\hline
\end{tabular}

Note. This table provides $P$ values for main effect derived through analysis of variance (Tukey HSD test); n.s. - non-sugnificant.

the soil of CONFYM treatment was by 3.8 times higher but in May 2010 by 2.1 times lower than that in the soil of ORGFYM treatment. In September 2010 and 2013, the denitrifying bacteria were counted in extraordinary low levels. The statistical analysis of our experiments showed that the sampling year had no significant impact on the number of denitrifying bacteria (Table 6).

Nitrifying bacteria. The results of our research showed that the nitrifying bacteria responded greatly to the soil nutritional status. In general, their numbers in the soil of ORG treatment in which only green manure as fertilizer was used were lower than those in the treatments where manure (ORGFYM) or manure plus mineral fertilizer (CONFYM) in addition to green manure were applied. The number of nitrifiers in the soil of ORGFYM treatment was by 2.2 and 1.6 times (as the average of research period in the fields No. 2 and No. 4 , respectively) higher than that in the ORG treatment. The numbers of nitrifying bacteria in ORGFYM and CONFYM treatments in which manure was applied, in general, were practically on the same level. The significant $(P<0.05)$ differences between these treatments became evident only in two cases. In May and September of 2009 , in the conventionally treated soils under barley (Table 5) and oats (Table 4) the number of nitrifiers was by 1.8 and 1.9 times higher than in the organically treated (ORGFYM) soil. In April 2011, there were very low levels of nitrifying bacteria detected. This was supposedly caused by too early sampling date because the soil bacteria probably were not sufficiently active. Several studies have reported rapidly altered activities of soil nitrifying and denitrifying bacteria in response to changing environmental conditions. The results of Szukics et al. (2010) showed that even short-term changes in the precipitation regime and soil temperature may rapidly affect the activity of both nitrifiers and denitrifiers. In our research, all the analysed factors, i.e. treatment, year and their interaction had significant impacts on the abundance of nitrifying bacteria (Table 6).

Azotobacteria. Aerobic bacteria belonging to the genus Azotobacter represent a diverse group of freeliving diazotrophic (able to use $\mathrm{N}_{2}$ as the sole nitrogen source) microorganisms commonly occurring in soil. Soil populations of Azotobacter spp. rarely exceed several thousand cells per gram of neutral or alkaline soils, in acid $(\mathrm{pH}<6.0)$ soils these bacteria are generally absent or occur in very low numbers (Martyniuk, 
Martyniuk, 2003). In our research, the occurrence of azotobacteria in the soil of different treatments was at low level. In several replicates of soil samples there were no azotobacteria detected. Besides, the great differences in numbers of these bacteria between the three replicates of the samples were established. Significant $(P<0.05)$ differences between treatments became evident in several cases. In May 2010, in the field No. 4 where red clover was grown the number of azotobacteria in the soil of the ORG treatment was by 3.5 and 5.7 times greater than in the soils of the CONFYM and ORGFYM treatments, respectively (Table 4). The determination of azotobacteria in the soil samples taken from the treatments of the field No. 2 indicated that the numbers of CFU in the CONFYM treatment were practically in all cases significantly $(P<0.05)$ lower than those in the soils of the organic treatments (Table 4$)$. In comparison with the ORG treatment, the soil of the CONFYM treatment contained by 2.1-6.1 times less azotobacteria depending on the year of research. Comparison of the ORGFYM and CONFYM treatments indicated that the numbers of azotobacteria in the conventionally treated soil were by 2.7-3.7 times lower. Such great decrease in the azotobacterial community in the CONFYM treatment was caused by the abundant application of pesticides, especially for control of late blight and pests in conventionally grown potato (2008). As mentioned in the methods, in that year potato was sprayed four times with fungicides and once with insecticide. The pesticides used repeatedly for potato protection had a harmful aftereffect on sensitive soil microorganisms also in succeeding years. From this viewpoint other researchers (Miloševic, Govedarica, 2002; Orr et al., 2011) also have stated that Azotobacter is especially sensitive to chemical inputs, such as pesticides. The statistical analysis showed that the significant impacts of the treatment $(P=0.039)$ and the year $(P=0.027)$ on the azotobacteria revealed only in the conditions of the crop rotation field No. 2 (Table 6).

\section{Conclusions}

1. Solid cattle manure applied in the organic fivefield crop rotation at a rate of $60 \mathrm{t} \mathrm{ha}^{-1}$ significantly $(P<0.05)$ increased the number of total bacteria in the soil.

2. The number of total bacteria in the soil depended on the weather conditions and sampling dates. The rainy and warm period before soil sampling affected positively the bacterial communities. Comparison of the results of the microbiological tests in spring and autumn in the same year revealed that the number of total bacteria in autumn was higher than in spring.

3 . The nitrifying bacteria responded to the soil nutritional status. Their abundance in the soil of the organic treatment in which only green manure as fertilizer had been used, was significantly $(P<0.05)$ lower than in the organic and conventional treatments where cattle manure or cattle manure plus mineral fertilizer and pesticides in addition to green manure had been applied. In general, there were no significant differences in the numbers of the soil total bacteria and nitrifying bacteria between the organic and conventional treatments in which both cattle manure was applied. The abundance of denitrifying bacteria did not depend on the farming treatments and weather conditions during the growth season.

4. The numbers of azotobacteria in the soil of different treatments were at low level. However, it became evident that the azotobacteria are very sensitive to pesticides. In the conventional treatment, the repeated spraying with fungicides and insecticide for potato protection decreased the number of azotobacteria as direct effect by 2.7 times and had the harmful aftereffect on these sensitive bacteria also in the succeeding years.

\section{Acknowledgements}

This paper presents research findings obtained through the long-term research project "The influence of organic and conventional farming on soil fertility, biodiversity and on crops yield and quality" funded by the Estonian Ministry of Agriculture. The authors would like to thank Mrs. Helgi Laitamm for her help.

Received 06032014 Accepted 05122014

\section{References}

Banks M. L., Kennedy A. C., Kremer R. J., Elvazi F. 2014. Soil microbial community responses to surfactants and herbicides in two soils. Applied Soil Ecology, 74: 121-20 http://dx.doi.org/10.1016/j.apsoil.2013.08.018

Bünemann E. K., Schwenke G. D., van Zwieten L. 2006. Impact of agricultural inputs on soil organic - a review. Australian Journal of Soil Research. 44: 379-406 http://dx.doi.org/10.1071/SR05125

Cheneby D., Brauman A., Rabary B., Philippot L. 2009. Differential responses of nitrate reducer community size, structure, and activity to tillage systems. Applied and Environmental Microbiology. 75 (10): 3180-3186 http://dx.doi.org/10.1128/AEM.02338-08

Chhotaray D., Achakzai A. K. K. 2012. Relationship between soil microbial activities with organic and conventional farming systems. International Journal of Sustainable Agriculture, 4 (3): 64-68

Clark I. M., Buchkina N., Jhurreea D., Goulding K. W. T., Hirsch P. R. 2012. Impacts of nitrogen application rates on the activity and diversity of denitrifying bacteria in the Broadbalk Wheat Experiment. Philosophical Transactions of the Royal Society B: Biological Sciences. 367 (1593): 1235-1244 http://dx.doi.org/10.1098/rstb.2011.0314

EVS-EN ISO 6887-1:2001. Microbiology of food and animal feeding stuffs - Preparation of test samples, initial suspension and decimal dilutions for microbiological examination - Part 1: General rules for the preparation of the initial suspension and decimal dilutions

EVS-EN ISO 4833-1:2013. Microbiology of the food chain. Horizontal method for the enumeration of microorganisms. Part 1 . Colony count at 30 degrees $\mathrm{C}$ by the pour plate technique (in Estonian)

Fliessbach A., Oberholzer H.-R., Gunst L., Mäder P. 2007. Soil organic matter and biological soil quality indicators after 21 years organic and conventional farming. Agriculture, Ecosvstems and Environment. 118: 273-284 http://dx.doi.org/10.1016/j.agee.2006.05.022

Graham M. H., Haynes R. J. 2005. Organic matter accumulation and fertilizer-induced acidification interact to affect soil microbial and enzyme activity on a long-term sugarcane management experiment. Biology and Fertility of Soils, 41: $249-256$ http://dx.doi.org/10.1007/s00374-005-0830-2

Grantina L., Keningsvalde K., Eze D., Petrina Z., Skrabule I., Rostocks N., Nikolajeva V. 2011. Impact of six year-long organic cropping on soil microorganisms and crop disease suppressiveness. Zemdirbyste-Agriculture, 98 (4): 399-408

Haleem A. M., Kasim S. A., Al-Timimy J. A. 2013. Effect of some organophosphorous insecticides on soil microorganisms populations under lab condition. World Environment, 3 (5): 170-173

Hayatsu M., Tago K., Saito M. 2008. Various players in the nitrogen cycle: diversity and functions of the microorganisms involved in nitrification and denitrification. Soil Science and Plant Nutrition, 54 (1): 33-45 
http://dx.doi.org/10.1111/j.1747-0765.2007.00195.x

ICC Standard No. 125. 1978. Method of determining the count of aerobic mesophilic bacteria (plate count method)

Janušauskaitė D., Arlauskienė A., Maikštènienė S. 2013. Soil mineral nitrogen and microbial parameters as influenced by catch crops and straw management. ZemdirbysteAgriculture. 100 (1): 9-18 http://dx.doi.org/10.13080/z-a.2013.100.002

Lauber C. L., Ramirez K. S., Aanderud Z., Lennon J., Fierer N. 2013. Temporal variability in soil microbial communities across land-use tvpes. The ISME Journal, 7 (8): 1641-1650 http://dx.doi.org/10.1038/ismej.2013.50

Lipson D. A. 2007. Relationships between temperature responses and bacterial community structure along seasonal and altitudinal gradients. FEMS Microbiology and Ecology. 59: 418-427 http://dx.doi.org/10.1111/j.1574-6941.2006.00240.x

Lone A. H., Raverkar K. P., Pareek N. 2014. In-vitro effects of herbicides on soil microbial communities. The Bioscan, 9 (1): 11-16

Martyniuk S., Martyniuk M. 2003. Occurrence of Azotobacter spp. in some Polish soils. Polish Journal of Environmental Studies, 12 (3): 371-374

Miller M. N., Dandie C. E., Zebarth B. J., Burton D. L., Goyer C., Trevors J. T. 2012. Influence of carbon amendments on soil denitrifier abundance in soil microcosms. Geoderma. 170: 48-55 http://dx.doi.org/10.1016/j.geoderma.2011.11.022

Miloševic N. A., Govedarica M. M. 2002. Effect of herbicides on microbiological properties of soil. Proceedings for Natural Sciences No. 102. Novi Sad, Serbia, p. 5-21

Monokrousos N., Papatheodorou E. M., Diamantopoulos J. D., Stamou G. P. 2006. Soil quality variables in organically and conventionally cultivated field sites. Soil Biology and Biochemistry. 38: 1282-1289 http://dx.doi.org/10.1016/j.soilbio.2005.09.023

Nannipieri P., Ascher J., Ceccherini M. T., Landi L., Pietramellara G., Renella G. 2003. Microbial diversity and soil functions. European Journal of Soil Science, 54: 655-670 http://dx.doi.org/10.1046/j.1351-0754.2003.0556.x
NMKL Method No. 86. 2006. Determination of aerobic microorganisms in foods at $30^{\circ} \mathrm{C}\left(4^{\text {th }}\right.$ ed.). Nordic Committee on Food Analysis

Orr C. H., James A., Leifert C., Cooper M., Cummings S. P. 2011. Diversity and activity of free-living nitrogen-fixing bacteria and total bacteria in organically and conventionally managed soils. Applied and Environmental Microbiology. 77 (3): 911-919 http://dx.doi.org/10.1128/AEM.01250-10

Parham J. A., Deng S. P., Raun W. R., Johnson G. V. 2002. Long-term cattle manure application in soil. I. Effect on soil phosphorus levels, microbial biomass $\mathrm{C}$, and dehydrogenase and phosphatase activities. Biology and Fertility of Soils, 35: 328-337

Pettersson M., Bååth E. 2003. Temperature-dependent changes in the soil bacterial community in limed and unlimed soil. FEMS Microbiology and Ecology. 45: 13-21 http://dx.doi.org/10.1016/S0168-6496(03)00106-5

Radivojevic L., Santric L., Stankovic-Kalezic R., Dragica B., Janjic V. 2003. Effects of metribuzin on the abundance and activity of some grouns of soil microorganisms. Pesticides, 18: 99-107 http://dx.doi.org/10.2298/PIF0302099R

Scherer H. W., Metker D. J., Welp G. 2011. Effect of long-term organic amendments on chemical and microbial properties of a luvisol. Plant, Soil and Environment, 57 (11): 513-518

Shannon D., Sen A. M., Johnson D. B. 2002. A comparative study of the microbiology of soils managed under organic and conventional regimes. Soil Use Management, 18: 274-283 http://dx.doi.org/10.1079/SUM2002130

Szukics U., Abell G. C. J., Hödl V., Mitter B., Sessitsch A., Hackl E., Zehmeister-Boltenstern S. 2010. Nitrifiers and denitrifiers respond rapidly to changed moisture and increasing temperature in a pristine forest soil. FEMS Microbiology and Ecologv. 72: 395-406 http://dx.doi.org/10.1111/j.1574-6941.2010.00853.x

Tan H., Barret M., Rice O., Dowling D. N., Burke J., Morrissey J. P., O'Gara F. 2012. Long-term agrichemical use leads to alterations in bacterial community diversity. Plant, Soil and Environment, 58 (10): 452-458

ISSN 1392-3196 / e-ISSN 2335-8947

Zemdirbyste-Agriculture, vol. 102, No. 1 (2015), p. 15-22

DOI $10.13080 /$ z-a.2015.102.002

\title{
Azoto apykaitos ciklo bakterijos dirvožemyje sèjomainose taikant ekologinę ir tradicinę žemdirbystès sistemas
}

\author{
M. Järvan, L. Edesi \\ Estijos augalų tyrimų institutas
}

\begin{abstract}
Santrauka
Tyrimo metu siekta ištirti ekologinio ir tradicinio ūkininkavimo įtaką nitrifikuojančioms, denitrifikuojančioms ir azoto bakterijoms, kurios dalyvauja dirvožemio azoto apykaitos cikle. Lauko bandymai atlikti 2007-2013

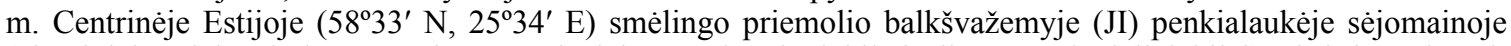
(žieminiai rugiai $\rightarrow$ bulvès $\rightarrow$ avižos $\rightarrow$ miežiai su raudonujų dobilų ịsèliu $\rightarrow$ raudonieji dobilai). Tirti šie variantai: ekologinis be méšlo, ekologinis su galvijų mėšlu ir tradicinis, kuriame buvo naudota méšlas, mineralinès trąšos ir pesticidai. Variantuose kietasis galvijų méšlas $\left(60 \mathrm{t} \mathrm{ha}^{-1}\right)$ buvo ịterptas bulvėms. 2007-2013 m. dirvožemio ėminiai mikrobiologiniams tyrimams buvo paimti iš dviejų sẻjomainos laukų $0-20 \mathrm{~cm}$ gylio. Taikant skaičiavimo lèkštelèse metodą, dirvožemio mėginiuose buvo nustatytas bendras bakterijų skaičius, azoto bakterijų, denitrifikuojančių ir nitrifikuojančių bakterijų kiekis.

Ekologinio ūkininkavimo variantuose patręšus galviju mėšlu, esmingai $(P<0,05)$ padidėjo bendras bakteriju bendrijų skaičius. Be to, nitrifikuojančios bakterijos jautriai reagavo ị dirvožemio maisto medžiagų kiekį. Jų kiekis ekologiniame be méšlo variante buvo esmingai $(P<0,05)$ mažesnis nei kituose variantuose. Tarp variantų nebuvo esminių $(P<0,05)$ denitrifikuojančių bakterijų skaičiaus skirtumų. Pakartotinis pesticidų ir insekticidų naudojimas bulvių apsaugai azoto bakterijų skaičių sumažino 2,7 karto ir turëjo neigiamos įtakos šioms jautrioms bakterijoms ir vèlesniais metais.
\end{abstract}

Reikšminiai žodžiai: azoto bakterijos, bendras bakterijų skaičius, denitrifikuojančios ir nitrifikuojančios bakterijos, kietasis galvijų měšlas, pesticidai, skaičiavimo lèkštelèse metodas. 